\title{
PERBEDAAN MODEL PEMBELAJARAN KOOPERATIF THINK-PAIR-SHARE (TPS) DENGAN MODEL PEMBELAJARAN NUMBERED HEAD TOGETHER (NHT) TERHADAP HASIL BELAJAR SISWA PADA MATERI MATEMATIKA DI SMPN I TANJUNG MORAWA
}

\section{ADE ISWIWIYANTI}

\author{
Guru SMP Negeri I Tanjung Morawa
}

\begin{abstract}
ABSTRAK
Penelitian ini bertujuan untuk mengetahui siswa dalam perbedaan hasil belajar yang memanfaatkan model pembelajaran Think Pair Share (TPS) dengan satu model pembelajaran Numbered Head Together (NHT) pada materi matematika di kelas II SMPN I Tanjung Morawa Tahun 2015 / 2016, dengan mengajar menggunakan model pembelajaran Kooperatif Think Pair Share (TPS) sebagai kelas eksperimen 1 dan mengajar menggunakan Kooperatif ini pembelajaran Numbered Head Together (NHT) 2 Kelas sebagai eksperimen. Jenis observasi ini adalah observasional percobaan, Populasi dalam pengamatan adalah siswa yang terdiri dari 2 kelas (kelas II 1 dan II 2). yang dijadikan sampel penelitian adalah seluruh populasi yang sering disebut probabilitas sampling, dengan jumlah 72 siswa. Pada kelas II 1 model pembelajaran Kooperatif Think Pair Share (TPS) dan kelas II 2 disebut dengan model pembelajaran Numbered Kepala Kooperatif ini Together (NHT).

Hasil penelitian ini menunjukkan bahwa hasil belajar siswa dengan menggunakan model pembelajaran Kooperatif Think Pair Share (TPS) mempunyai perbedaan dari pembelajaran Numbered Kepala Kooperatif ini Together (NHT), di mana didapatkan $1=83,00$ dengan SD x $1=8754$ untuk kelas eksperimen 1 sementara itu pada 2 kelas eksperimen didapat $2=80.889$ oleh SD x $2=7672$. Data hasil analisis ini menunjukkan $t$ komputasi t tabel (0.348 1.670). Jadi dapat disimpulkan bahwa tidak ada perbedaan antara hasil siswa yang diajarkan oleh model pembelajaran Kooperatif Think Pair Share (TPS) dengan siswa yang belajar dengan model pembelajaran Numbered Kepala Kooperatif ini Together (NHT) pada materi pelajaran matematika di SMPN I Tanjung Morawa
\end{abstract}

Kata Kunci : Model Pembelajaran,Kooperatif Think Pair Share,Numbered Together

\section{PENDAHULUAN}

Pemerintah telah melakukan berbagai upaya dalam meningkatkan dunia pendidikan serta sumberdaya manusia diantaranya adalah: penyempurnaan kurikulum pendidikan, memperbesar kesempatan belajar dengan memberikan fasilitas tekhnologi,pelatihan guru,dosen pada perguruan tinggi dan lain-laun. untuk program semua itu pemerintah sudah menganggarkan dana APBN sebesar 20\% atau lebih tepatnya dikatakan untuk dunia pendidikan, tapi sayangnya semuanya itu belum sanggup menjawab tantangan zaman karena mutu pendidikan masih tetap rendah. Indikator rendahnya mutu pendidikan tersebut ditunjukkan dengan banyaknya siswa maupun mahasiswa yang telah menyelesaikan studinya dari suatu jenjang pendidikan belum siap pakai untuk di dunia kerja sehingga membuat membengkaknya jumlah pengangguran intelektual dari tahun ke tahun, karena mahasiswa tidak dibekali keterampilan yang dapat digunakan di lapangan kerja. 
Mata pelajaran matematika adalah salah satu mata pelajaran yang mampu menjelaskan konsep, mengidentifikasi,mengukur dan mengendalikan dengan kondisi terjadinya deviasi yang menyebabkan kerugian. Dengan mengharapan siswa mampu menjelaskan konsep matematika yang dilakukan dengan baik dapat memberikan kesempatan bagi siswa untuk mengembangkan kemampuan-kemampuanya, Ketika peneliti melakukan pembelajaran dikelas, peneliti mendapat pengalaman, bahwa hasil materi yang disampaikan belum menunjukkan perkembangan yang berarti hal ini dibuktikan dengan belum tercapainya criteria ketuntasan minimal. siswa masih belum secara maksimal menjadi aktif dalam setiap kegiatan pembelajaran bahkan mahasiswa masih banyak yang pasif sehingga kemampuan berpikir kritis yang seharusnya dibiasakan sejak dini masih belum tercapai. Ini salah satu penyebabnya karena dosen tidak menggunakan model pembelajaran dan hanya berpusat kepada guru. Dengan demikian, perlu dilakukan pembenahan pada sistem pembelajarannya. Hal ini dapat dilakukan guru di kelas dengan menerapkan model pembelajaran yang berpusat pada kompetensi siswa.

Berdasarkan data dari kelas pada SMPN I Tanjung Morawa, ditemui dalam mata pelajaran matematika TA. 2015/2016, lebih dari 50\% siswa memperoleh nilai di bawah 70-74. Sementara Kriteria Ketuntasan Minimum adalah 85 s/d 100. Rendahnya hasil belajar tersebut disebabkan berbagai faktor, salah satunya model pembelajaran yang digunakan guru belum sesuai dengan kondisi siswa. Dalam penyampaian materi yang sangat efektif adalah menerapkan metode diskusi yang erat hubungannya dengan memecahkan masalah (Muhibbin Syah,2000). Oleh karena itu, dalam memilih suatu model pembelajarn harus memilki pertimbangan-pertimbangan. Salah satu pertimbangannya yaitu dengan menerapakan model pembelajaran yang memberikan kesempatan bagi peserta didik untuk mandiri berkolaborasi dan bersosialisasi. (Rauza,2013), karena jika pada tahapan Think guru akan mengkaitkan dengan pelajaran dan siswa dianjak untuk memecahkan dengan mandiri. sehingga minat belajar serta hasil belajar akademis,penerimaan keberagaman serta pengembangan keterampilan social akan meningkat. Dan akan sesuai dengan model pembelajaran Kooperatif.

Artzt dan Newman menyatakan bahwa dalam belajar kooperatif siswa belajar dalam satu tim dalam menyelesaikan tugas-tugas kelompok untuk mencapai tujuan bersama,(Trianto,2009) selajutnya dalam tambahan tujuan dibentuknya kelompok tersebut adalah untuk memberikan kesempatan kepada siswa untuk dapat terlibat secara aktif dalam proses berpikir dan kegitan belajar. Banyak model pembelajaran kooperatif yang telah dibuat para ahli diantaranya model pembelajaranThink-Pair-Share (TPS) dan Numbered Head Together (NHT)

Pembelajaran TPS merupakan suatu cara yang efektif untuk membuat variasi pola Susana diskusi kelas. Dengan asumsi resitasi atau diskusi membutuhkan pengaturan untuk mngendalikan kelas secara keseluruhan, dan prosedur yang digunakan dalam think-pair-share dapat memberi siswa lebih banyak waktu berpikir, untuk merespon dan saling membantu. Guru hanya melengkapi penyajian singkat atau siswa membaca tugas, atau situasi menjadi tanda Tanya. Model pembelajaran TPS adalah model berfiki,berpasangan,berbagi merupakan belajar komperatif yang mempengaruhi interaksi siswa,dan menghendaki siswa bekerja saling membantu dan dirincikan oleh penghargaan komperatif daripada penghargaan individu (Ibrahim,2000,3). Dengan diterapkannya model pembeljaran TPS ini diharapkan siswa akan lebih aktif dalam peroses belajar mengajar. Yang akhirnya akan meningkatkan kemampuan siswa. 
Numbered Head Together (NHT) atau penomoran berpikir bersama adalah jenis pembelajaran kooperatif yang dirancang untuk mempengaruhi pola interaksi mahasiswa dan sebagai alternative terhadap struktur kelas tradisional. Numbered Head Together (NHT) pertama kali dikembangkan oleh Kagen (1993) untuk melibatkan lebih banyak siswa dalam menelaah materi yang tercakup dalam suatu pelajaran dan mengecek pemahaman mereka terhadap isi pelajaran tersebut (Trianto, 2009)

Model pembelajaran TPS dan NHT ini diharapakan mampu meningkatkan prestasi siswa, karena pada model pembelajaran TPS semua siswa harus memikirkan permasalahan yang dilontarkan seorang dguru secara individu selanjutnya siswa mendiskusikan pemikiran awal mereka dengan pasangannya, setelah didapat kesepakatan baru mereka mempersentasikan hasil diskusi mereka. Sedangkan model pembelajaran NHT, semua siswa harus bealajar, berdiskusi dan mengetahui jawaban dari permasalahn yang diberikan seorang guru dengan teman kelompoknya karena yang mempersentasikan hasil diskusi diambil secara acak dari setiap kelompoknya dan hanya satu orang saja.

Berdasarkan hal ini peneliti tertarik untuk mengadakan penelitian supaya dapat membedakan hasil belajar siswa yang menggunakan model pembelajaran TPS dan NHT pada mata pelajarana matematika. Karakteristik materi ini adalah banyak masalah-masalah yang perlu dipecahakan baik secara individu maupun kelompok. Yang cocok digunakan dengan model pembelajran TPS dan NHT. Oleh sebab itu akan menguji cobakan kedua model pembelajaran ini agar dapat membedakan hasil belajar siswa dengan menggunakan dua model tersebut.

\section{KAJIAN TEORI}

\section{Pengertian Pembelajaran}

Pembelajaran adalah suatu proses atau cara mengajarkan berbagai ilmu pengetahuan kepada siswa agar memperoleh kepandaian atau ilmu pengetahuan. pembelajaran dilaksanakan dalam kegiatan belajar yang melibatkan seorang staf pengajar (guru) dengan orang yang diajar (siswa). Proses pembelajaran yang dilakukan bukan hanya sekedar informasi dari guru, akan tetapi melibatkan berbagai kegiatan dan tindakan yang kompleks, terutama bila diinginkan hasil belajar yang efektif.

Pengertian model yang dikaitkan dengan kata pembelajaran adalah pola, ragam atau acuan yang dipergunakan untuk merencanakan seluk beluk pengajaran berbagai ilmu pengetahuan kepada siswa agar memperoleh ilmu pengetahuan. Model pembelajaran adalah kerangka konseptual yang menggambarkan prosedur sistematis dalam mengorganisasikan pengalaman belajar untuk mencapai tujuan belajar (Trianto,2009). Fungsi model pembelajaran adalah sebagai pedoman bagi perancang pengajaran dan para guru dalama melaksanakan pembelajaran. Pemilihan model pemberlajaran sangat dipengaruhi oleh sifat dari materi yang akan diajarkan, tujuan yang akan dicapai dalam pembelajaran tersebut, serta tingkat kemampuan peserta didik.

Jadi, model pembelajaran adalah kerangka konseptual yang melukiskan prosedur sistematik dalam mengorganisasikan pengalaman belajar untuk mencapai tujuan belajar tertentu dan berfungsi sebagai pedoman bagi perancang pembelajaran dan para guru dalam merancang dan melaksanakan pembelajaran.

Hasil belajar atau achievement merupakan realisasi atau pemekaran dari kecakapan-kecakapan potensial atau kapasitas yang dimiliki seseorang. Penguasaan hasil belajar seseorang dapat dilihat dari perilakunya, baik perilaku dalam penguasaan 
pengetahuan, keterampilan berpikir maupun keterampilan motorik. Hampir sebagian tersebar dari kegiatan atau perilaku yang diperlihatkan seseorang merupakan hasil dari belajar.Di sekolah hasil belajar ini dapat dilihat dari penguasaan siswa akan mata pelajaran yang ditempuhnya. Tingkat penguasaan pelajaran atau hasil belajar dalam mata pelajaran tersebut di sekolah dilambngkan dengan angka-angka atau huruf, seperti angka 0 - 10 pada pendidikan dasar dan menengah dan huruf $\mathrm{A}, \mathrm{B}, \mathrm{C}, \mathrm{D}$ pada pendidikan tinggi. Sebenarnya hampir seluruh perkembangan atau kemajuan hasil belajar merupakan hasil belajar, sebab proses belajar tidak hanya berlangsung disekolah tetapi juga di tempat kerja dan dimasyarakat.

Bakat dan hasil belajar dapat diukur. Alat untuk mengukur bakat disebut tes bakat (aptitude test), sedang alat untuk mengukur hasil belajar disebut tes hasil belajar atau tes prestasi belajar atau achievement tes. Sesungguhnya baik untuk tes bakat maupun tes hasil belajar diperlukan tes baku atau tes standar. Tes baku ini umunya hanya bisa dilaksanakan pada pengembangan tes bakat, sedang pada tes hasil belajar pembakuan tes tidak selalu dapat dilakukan, karena guru-guru umumya didesak waktu untuk segera melakukan penilaian (sukmadianata, 2003).

\section{Model Pembelajaran Koopertif Learning}

Model pembelajara koperatif tentu saja bukan hal baru. Para guru sudah menggunakannya selama bertahun-tahun dalam bentuk kelompok laboratorium, kelompok tugas, kelompok diskusi dan sebagainya. Namun, penelitian terakhir di Amerika dan beberapa Negara lain telah menciptakan metode-metode pembeljaran kooperatif yang sistematik dan praktis ditunjukkan untuk digunakan sebagai elemen utama dalam pola pengaturan dikelas. Metode-metode ini sekarang telah digunakan secara ekstensif dalam tiap subjek yang dapat dikonsepkan, pada tingkat kelas mulai dari taman kanak-kanak sampai perguruan tinggi, dan pada berbagai macam sekolah di seluruh dunia (Slavin, 2005).

Model pembelajaran cooperative learning belum banyak diterapkan dalam pendidikan Indonesia walaupun orang Indonesia sangat membanggakan sifat gotong royong dalam kehidupan bermasyarakat. Kebanyakan pengajar enggan menerapkan sitem kerja sama di dalam kelas karena beberapa alasan. Alasan yang utama adalah kekhawatiran bahwa akan terjadi kekacauan di kelas dan siswa tidak belajar jika mereka ditempatkan dalam grup. Selain, itu banyak orang mempunyai kesan negative mengenai kerja sama atau belajar dalam kelompok. Banyak juga siswa tidak senang disuruh bekerja sama dengan yang lain. Siswa yang tekun merasa harus bekerja melebihi siswa yang lain dalam grup mereka, sedangkan mahasiswa yang kurang mampu merasa minder ditempatkan dalam satu grup dengan mahasiswa yang lebih pandai. Siswa yang tekun juga merasa temannya yang kurang mampu hanya menumpang saja pada hasil jerih payah mereka (Lie, 2002).

\section{Pembelajaran Kooperatif Tink-Pair-Share (TPS)}

Teknik belajar mengajar Berpikir-Berpasangan-Berbagi dikembangkan oleh Frank Lyman (Tink-Pair-Share) sebagai struktur kegiatan pembelajaran Cooperative Learning. Teknik ini memberi siswa kesempatan untuk bekerja sendiri serta bekerja sama dengan orang lain. Keunggulan dari teknik ini adalah optimalisasi partisipasi siswa. Dengan metode klasikal yang memungkinkan hanya satu maju dan membagikan hasilnya untuk seluruh kelas, teknik Tink-Pair-Share ini memberi kesempatan sedikitnya delapan kali lebih banyak kepada setiap untuk dikenali dan menunjukkan partisipasi mereka kepada orang lain (Lie, 2001 
Adapun langkah - langkah metode pembelajaran Tink-Pair-Share (TPS) adalah sebagai berikut :

1. Lanagkah-langkah TPS secara umum

a. Langkah 1: Bepikir (Thinking)

mengajukan suatu pertanyaan atau masalah yang dikaitkan dengan pelajaran, dan meminta siswa menggunakan waktu beberapa menit untuk berpikir sendiri jawaban atau masalah. siswa membutuhkan penjelasan bahwa berbicara atau mengerjakan bukan bagian berpiki.

\section{b. Langkah 2: Berpasangan (Pairing)}

Selanjutnya guru meminta siswa untuk berpasangan dan mendiskusikan apa yang mereka peroleh. Intraksi selama waktu yang sediakan dapat menyatukan jawaban jika suatu pertanyaan yang diajukan atau menyatukan gagasan apabila suatu masalah khusus yang diidentifikasi. Secara normal dosen memberi waktu tidak lebih dari 4 atau 5 menit untuk berpasangan.

\section{c. Langkah 3: Berbagi (Sharing)}

Pada langkah akhir, dosen meminta pasangan-pasangan untuk berbagi dengan keseluruhan kelas yang telah mereka bicarakan. Hal ini efektif untuk berkeliling ruagan dari pasangan ke pasangan dan melanjutkan sampai sekitar sebagian pasangan mendapatkan kesempatan untuk melaporkan (Tjokrodihardjo,2003).

2. Langkah-lngkah yang harus dilakukakan guru selama KBM

Adapun langkah-langkah yang harus dilakukan guru pada model diskusi ThinkPair-Share dapat kita lihat pada table dibawah ini.

Tabel : 1

Langkah-langkah penyelenggaraan TPS yang dilakukan guru

\begin{tabular}{|c|l|}
\hline \multicolumn{1}{|c|}{ Tahap } & \multicolumn{2}{|c|}{ Kegiatan guru } \\
\hline $\begin{array}{c}\text { Tahap 1 menyampaikan tujuan } \\
\text { dan mengatur mahasiswa }\end{array}$ & $\begin{array}{l}\text { 1) Menyampaikan pendahuluan,(a).motivasi, } \\
\text { (b)menyampaikan tujuan dasar diskusi, } \\
\text { (c)apersepsi } \\
\text { 2) Menjelaskan tujuan diskusi }\end{array}$ \\
\hline \multirow{3}{*}{ Tahap 2 mengarahkan diskusi } & $\begin{array}{l}\text { 1) Mengajukan pertanyaan awal/permasalahan } \\
\text { 2) Modeling }\end{array}$ \\
\hline Tahap penyelenggaraaan diskusi & $\begin{array}{l}\text { 1) } \text { membimbing/mengarahkan siswa dalam } \\
\text { mengerjakan tugas secara mandiri(think) } \\
\text { bepasanagan (pair) }\end{array}$ \\
& 3) membimbing/mengarahakan siswa dalam \\
berbagi (share) & 4) menerapkan waktu tunggu \\
& 5) membimbing kegitan siswa \\
\hline
\end{tabular}




\begin{tabular}{|c|l|}
\hline Tahap 4 mengakhiri diskusi & menutup diskusi \\
\hline $\begin{array}{c}\text { Tahap 5 melakukan Tanya } \\
\text { jawab singkat tentang proses } \\
\text { diskusi }\end{array}$ & $\begin{array}{c}\text { membantu siswa membuat rangkuman diskusi } \\
\text { dengan Tanya jawab singkat. }\end{array}$ \\
\hline
\end{tabular}

\section{Pembelajaran Kooperatif Numbered Head Together (NHT)}

Numbered Head Together (NHT) atau penomoran berpikir bersama adalah jenis pembelajaran kooperatif yang dirancang untuk mempengaruhi pola interaksi siswa dan sebagai alternative terhadap struktur kelas tradisional. Numbered Head Together (NHT) pertama kali dikembangkan oleh Kagen (1993) untuk melibatkan lebih banyak siswa dalam menelaah materi yang tercakup dalam suatu materi dan mengecek pemahaman mereka terhadap isi materi tersebut.

Secara umum, guru menggunakan struktur empat fase sebagai sintaks model NHT, yaitu:

\section{Fase 1 : Penomoran}

Dalam fase ini, guru membagi siswa ke dalam kelompok 3-5 orang dan kepada setiap angggota kelompok diberi nomor antara 1 sampai 5.

\section{Fase 2 : Mengajukan pertanyaan}

Guru mengajukan sebuah pertanyaan kepada siswa. pertanyaan dapat bervariasi. Pertanyaan dapat spesifik dan dalam bentuk kalimat tanya.

\section{Fase 3 : Berfikir bersama}

Siswa menyatukan pendapatnya terhadap jawaban pertanyaan itu dan meyakinkan tiap angggota dalam timnya mengetahui jawaban tim.

\section{Fase 4 : Menjawab}

Guru memanggil satu nomor tertenu, kemudian siswa yang nomornya sesuai mengacungkan tangannya dan mencoba untuk menjawab pertanyaan untuk seluruh kelas.(Trianto,2009).

Selanjutnya Dalam implementasi Numbered Head Together (NHT), guru memberi tugas kemudian hanya siswa bernomor, yang berhak menjawab (mencegah dominasi siswa tertentu).

\section{Kelebihan Dan Kekurangan (NHT)}

Adapaun yang menjadi kelebihan dari model pembelajaran ini adalah :

1. Dapat meningkatakan kerja sama diantara siswa, sebab dalam pembelajaran mahasiswa ditempatkan dalam satu kelompok untuk berdiskusi.

2. Dapat meningkatkan tanggung jawab siswa secara bersama, sebab masing-masing kelompok diberi tugas yang berbeda untuk dibahas.

3. Melatih siswa untuk menyatukan pikiran, karena NHT mengajak siswa untuk menyatukan persepsi dalam kelompok.

4. Melatih mahasiswa untuk menghargai pendapat orang lain, sebab dari hasil diskusi diminta tanggapan dari peserta lain.

Sedangkan yang menjadi kekurangan dalam model ini adalah:

1. Siswa dimungkinkan kan bingung kenapa dalam kelompok masih ada lagi nomor.

2. Sulit menyatukan pikiran siswa dalam satu kelompok, karena masing-masing mahasiswa mempertahan egoisnya. 
3. Diskusi seringkali menyita waktu yang cukup lama jadi bisa-bisa waktu tidak cukup dalam melaksanakan perose belajar-mengajar

4. Sering terjadi perdebatan yang kurang bermanfaat, karena yang diperdebatkan itu adakalanya bukan mempersoalkan materi yang urgin atau substansif, tetapi pada materi ayng kurang penting

5.Siswa yang pendiam akan mersa sulit untuk berdiskusi didalam kelompok dan susah dimitai pertanggung jawabanya (Istarani, 2011).

\section{Kerangka Berpikir}

Berdasarkan paparan teoritis di atas dapat dimaknai, bahwa para dosen selalu berusaha memilih metode pengajaran yang paling tepat dipandang dan lebih efektif daripada metode lainnya sehingga kecakapan dan pengetahuan yang diberikan oleh guru itu benar-benar menjadi milik siswa. Penggunaan metode yang tepat dalam pelajaran akan dapat membantu siswa untuk aktip, saling komunikatif dan intraktif dan bagi guru akan lebih mudah menyampaikan informasi materi pelajaran yang tentunya akan lebih mudah pula bagi siswa untuk menguasai dan memahami materi pelajaran yang akan disampaikan tersebut, sehingga diharapkan terjadi peningkatan kualitas pembelajaran dan pemahaman terhadap materi. Peningkatan kualitas pembelajaran ditunjukkan oleh kegiatan peningkatan aktifitas belajar siswa, respon positif terhadap kegiatan belajar mengajar yang dilaksanakan oleh dosen dan peningkatan hasil belajar.

Berdasarkan penelitian pendahulu (Darianti,2011) hasil belajar siswa dengan menerapakan model pembelajaran kooperatif TPS hasilnya $87.17 \%$ siswa telah tuntas dan penelitian (Hasibuhuan,2010) dengan memenerapakan model pembelajaran TPS nilai rata-rata siswa mencapai 77,08 sedangkan (Hafiza,2010) dengan menerapkan model pembelajaran TPS memperoleh nilai rata-rata siswa sebesar 76,8.

Penelitian (Wati, 2010) dengan menerapkan model pembelajaran NHT siswa yang tuntas sebesar 77,5\% dan penelitian (Sebayung, 2010) nilai rata-rata siswa mencapai 80,53\% dengan menerapkan model pembelajaran NHT, sedangkan penelitian (Hafiza, 2010) nilai rata-rata siswa sebesar 73,03.

Alur penelitian yang akan dilaksanakan dapat dilihat dalam skema gambar 3.1 dibawah ini: 


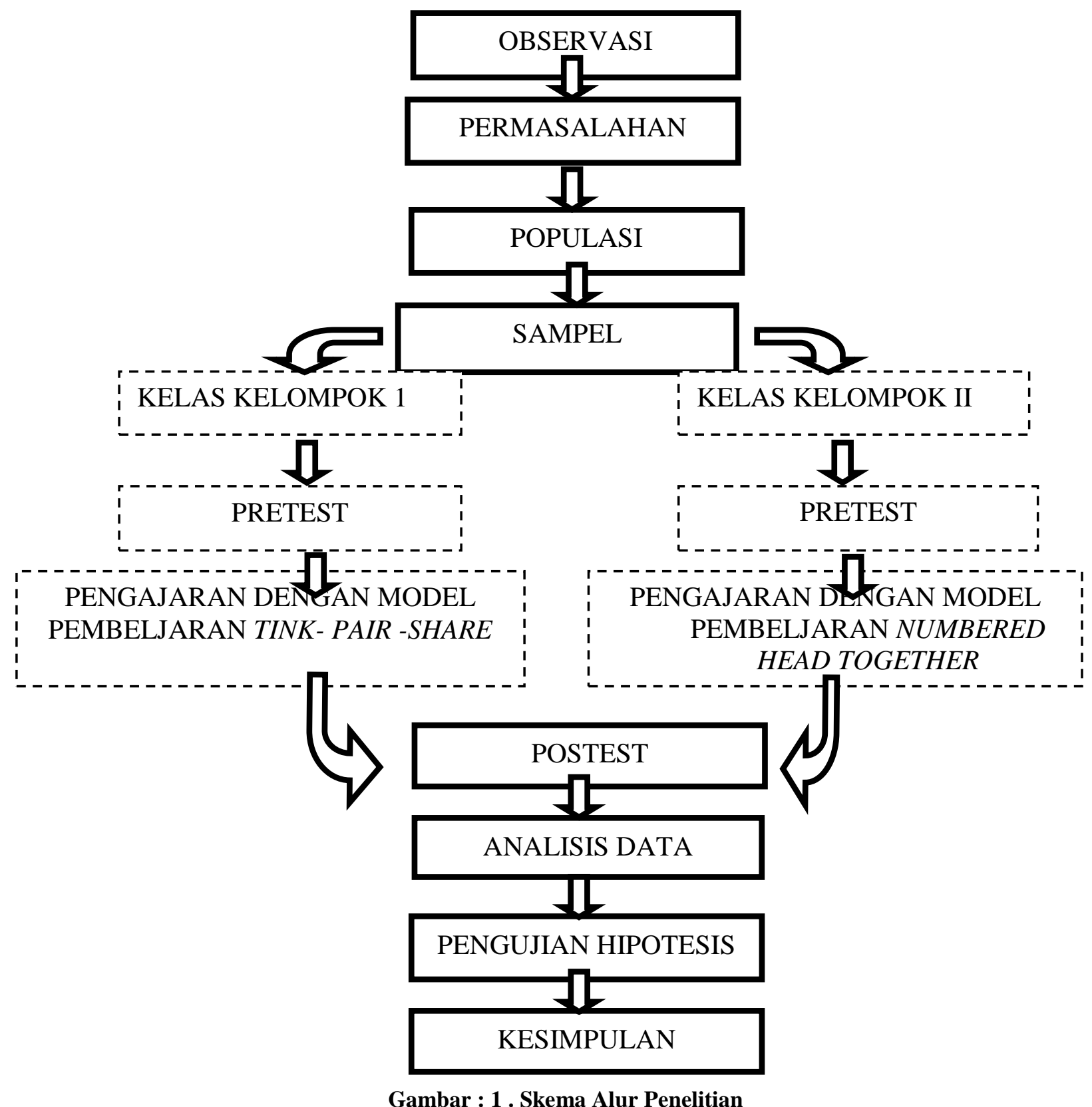

\section{Hipotesis}

Ho : Tidak ada perbedaan hasil pembelajaran mahasiswa pada pembelajaran Permasalahan Lingkungan Ekternal dan Internal melalui Model pembeljaran TinkPair-Share (TPS) dengan Model pembeljaran Numbered Head Together (NHT) di kelas II SMPN I Tanjung Morawa

Ha : Ada perbedaan hasil Pembelajaran mahasiswa pada pembelajaran Permasalahan Lingkungan ekternal dan internal melalui Model pembeljaran Tink-Pair-Share (TPS) dengan Model pembelajaran Numbered Head Together (NHT) di kelas II SMPN I Tanjung Morawa 


\section{METODE PENELITIAN}

\section{Sampel}

Sampel dalam penelitian ini adalah sampel total yaitu seluruh kelas II dengan jumlah siswa sebanyak 72 orang. Penentuan penerapan model pembelajran dilakukan secara random, dengan membuat undian; Hasil undian diperoleh kelas II-1 diberi perlakuan model pembelajaran koopertife tife Tink-Pair-Share (TPS) sedangkan kelas II-2 diberi perlakuan dengan model pembelajaran Numbered Head Together (NHT)

\section{Teknik Pengumpul Data}

Data dikumpulkan melalui tes. Tes digunakan untuk mengetahui kemampuan hasil pembelajaran siswa sebelum dan sesudah pengajaran. Alat pengumpul data dalam penelitian ini adalah tes berbentuk pilihan berganda sebanyak 40 soal, yang terdiri dari 4 pilihan jawaban a,b,c dan d. Untuk mengetahui kebenaran tes, maka sebelum digunakan tes terlebih dahulu diujikan pada siswa diluar sampel sehingga dapat diketahui tentang validitas tes, reliabilitas tes, tingkat kesukaran tes, dan daya pembeda tes.

\section{Teknik Analisis Data}

Setelah data diperoleh, data diolah dengan teknik menghitung rata-rata dan simpangan baku untuk setiap kelas, dimana:

Menghitung nilai rata-rata skor dengan rumus :

$$
\bar{X}=\frac{\sum X_{1}}{N}
$$

Menghitung Standar Deviasi dengan rumus :

$$
S=\sqrt{\frac{N \sum X_{1}-\left(\sum X_{1}\right)^{2}}{N(N-1)}}
$$

(Sudjana, 2002)

Dimana:

$$
\begin{array}{ll}
\mathrm{S} & =\text { Simpangan baku } \\
\mathrm{X} & =\text { Rata-rata hitung }
\end{array}
$$

\section{Variabel Penelitian}

Adapun variabel penelitian ini adalah:

a. Variabel bebas (X) : Model pembelajaran Tink-Pair-Share (TPS) dengan model pembelajaranNumbered Head Together (NHT)

b. Variabel Terikat (Y) : Hasil belajar siswa pada materi pokok Permasalahan

\section{Jenis Penelitian} Lingkungan di SMPN I Tanjung Morawa.

Jenis penelitian yang digunakan dalam penelitian ini adalah penelitian eksperimen semu. Dalam pelaksanaannya, peneliti melibatkan perlakuan yang berbeda pada kedua kelas. Untuk kelas yang pertama atau kelompok 1 diberi pengajaran dengan metode Tink-Pair-Shre(TPS)dan kelas yang ke dua atau kelompok 2diberi pengajaran dengan metode Numbered Head Together (NHT) 


\section{Tahap Pelaksanaan Penelitian}

\section{a. Melakukan Pretest}

Pre-test diadakan untuk kedua kelompok yang akan diteliti baik pada kelompok eksperimen I (teknik Tink-Pair-Share) maupun kelompok II (teknik Numbered Head Together) dengan soal yang sama sebelum pelajaran dimulai.

b. Melaksanakan Proses Belajar Mengajar

1. Kelompok I ( Kelas dengan teknik Tink-Pair-Share)

- Membuka pelajaran dan memperkenalkan Tink-Pair-Share

- Melaksanakan tes awal

- Menyajikan materi sebagai pengantar

- Melaksanakan pembelajaran dengan Tink-Pair-Share

- Menyimpulkan materi pembelajaran bersama-sama dengan siswa

2. Kelompok II (kelasdengan teknikNumbered Head Together )

- Membuka pelajaran dan memperkenalkan Numbered Head Together

- Melaksanakan tes awal

- Menyajikan materi sebagai pengantar

- Melaksanakan pembelajaran dengan Numbered Head Together

- Menyimpulkan materi pembelajaran bersama-sama dengan siswa

\section{c. Pelaksanaan Postest}

Setelah pengajaran materi pokok bahasan selesai, selanjutnya diberikan postest kepada kedua kelompok untuk memperoleh data hasil belajar siswa.

\section{d. Pengujian Hipotesis}

Untuk menguji hipotesis digunakan uji t dengan taraf signifikan $\alpha=0,05$ dengan derajat kebebasan $(\mathrm{dk})=\mathrm{n}_{1}+\mathrm{n}_{2}-2$.

$$
\begin{gathered}
t=\frac{\overline{X_{1}}-\overline{X_{2}}}{S \sqrt{\frac{1}{n_{1}}+\frac{1}{n_{2}}}} \\
S^{2}=\frac{\left(n_{1}-1\right) S_{1}^{2}+\left(n_{2}-2\right) S_{1}^{2}}{n_{1}+n_{2}-2}(\text { Sudjana, 200) }
\end{gathered}
$$

Dimana:

$\overline{\mathrm{X}}_{1}=$ Skor rata-rata kelas eksperimen I ( Menggunakan model pembelajaran Think Pair Share)

$\overline{\mathrm{X}}_{2}=$ Skor rata-rata kelas eksperimen II (menggunakan Model Pembelajaran Numbered Head Together)

$\mathrm{n}_{1}=$ Jumlah sampel eksperimen I (menggunakan pembelajaran model TPS).

$\mathrm{N}_{2}=$ Jumlah sampel eksperimen II (menggunakan pembelajaran model NHT)

$\mathrm{S}_{1}{ }^{2}=$ Varians kelas eksperimen I (menggunakan pembelajaran model TPS).

$\mathrm{S}_{2}{ }^{2}=$ Varians kelas eksperimen II (menggunakan pembelajaran model NHT).

$\mathrm{S}=$ Standart deviasi gabungan dari kedua kelas sampel (kelompokeksperimen I dan kelompok eksperimen II).

Pengujian hipotesis dilakukan sebagai berikut :

Jika $t_{\text {hitung }}>t_{\text {tabel }}$ maka Ho ditolak dan Ha diterima

Jika $t_{\text {hitung }}<t_{\text {tabel }}$ maka Ho diterima dan Ha ditolak 
Kriteria pengujian adalah Ho diterima jika $t_{1-1 / 2}>t>t_{1-1 / 2} \alpha$, dimana $t_{1-1 / 2} \alpha$ diperoleh dari daftar distribusi $t$ dengan $\mathrm{dk}=\left(\mathrm{n}_{1}+\mathrm{n}_{2}-2\right)$ dan peluang $\left(\mathrm{t}_{1-1 / 2 \alpha}\right)$. Untuk harga-harga t lainnya Ho ditolak.

Untuk melihat keefektifitas uji hipotesis dari hasil post test maka perlu dianalisis data ketuntasana hasil belajar siswa dan ketercapaian tujuan pembelajaran khusus (TPK) siswa.

\section{c. Data Hasil Penelitian}

\section{Data Pre-test}

Sebelum diberikan perlakuan terlebih dahulu dilakukan pre-test. Pre-test dilakukan dengan tujuan untuk mengetahui kemampuan awal siswa sebelum materi diajarkan. Berdasarkan hasil perhitungan pre-test diperoleh nilai rata-rata pre-test siswa kelas yang akan diajarkan dengan model pembelajran TPS sebesar 47,222 dengan standar deviasi sebesar 8,754 sedangkan nilai rata-rata pre-test siswa yang akan dijarakan dengan model pembelajran NHT sebesar 45,667 dengan standar deviasi sebesar 7,672.

\section{Data Post-test}

Dari hasil post-test diketahui nilai rata-rata siswa pada kelas TPS sebesar 83,00 dengan standar deviasi (SD) sebesar 11,043 sedangkan pada kelas NHT diperoleh nilai rata-rata sebesar 80,889dengan SD sebesar 9,896.

\section{Hasil Uji Hipotesis}

\section{Tabel :4}

Ringkasan Pengujian Hipotesis

\begin{tabular}{|c|l|c|c|c|c|}
\hline No & $\begin{array}{c}\text { Model } \\
\text { Pembelajaran }\end{array}$ & $\begin{array}{c}\text { Nilai } \\
\text { Rata- } \\
\text { rata }\end{array}$ & $\mathbf{t}_{\text {hitung }}$ & $\mathbf{t}_{\text {tabel }}$ & \multicolumn{1}{|c|}{ Kesimpulan } \\
\hline 1 & $\begin{array}{l}\text { Think-Pair- } \\
\text { Share (TPS) }\end{array}$ & 83,000 & 0,348 & 1,670 & $\begin{array}{l}\text { Tidak ada perbedaan antara } \\
\text { hasil belajar siswa yang diajar } \\
\text { dengan model pembelajaran } \\
\text { kooperatif Think-Pair- } \\
\text { Sharedengan Numbered Head } \\
\text { Together. }\end{array}$ \\
\hline 2 & $\begin{array}{l}\text { Numbered Head } \\
\text { Together (NHT) }\end{array}$ \\
\hline
\end{tabular}

\section{PEMBAHASAN}

Hasil belajar siswa yang diajarkan dengan model pembelajaran TPS lebih baik daripada pembelajaran yang dilakukan dengan model pembelajar NHT hal ini senada dengan Hasil penelitian sebelumnya oleh(Hafiza, 2010) bahwa hasil belajar siswa yang diberi pengajaran menggunakan Think-Pair-Share lebih tinggi dibandingkan hasil belajar siswa yang diberi pengajaran dengan menggunakan model pembelajaran Numbered Head Toggether dengan nialai rata-rata siswa yaitu 76,8 dan 73,03. Hal senada juga dikemukakan (Sari Hartati dan Suciati Sudarisman) bahwa model pembelajaran kooperatif tipe TPS lebih tinggi dari model pembelajran kooperatip tipe NHT. hal ini diyakini karena model pembelajaran koopertaif tipe TPS lebih banyak memberikan kesempatan peserta didik untuk melakukan eksplorasi dan elaborasi dalam rangka mengkontruksi pengetahuan sendiri dalam tahapan sintak pada model pembelajaran koopertaif tipe TPS khususnya pada waktu proses thinking sebelum 
melakukan sintak pairing, sedangkan pada model pembelajaran koopertaif tipe NHT, tidak menghabiskan cukup banyak waktu untuk melakukan hal tersebut

Hasil pengujian hipotesis dengan menggunakan uji-t untuk mengetahui ada tidaknya perbedaan antara hasil belajar siswa kelas Think-Pair-Share (TPS) dengan hasil belajar siswa kelas Numbered Head Together (NHT). Pengujian ini dilakukan pada taraf signifikan $\alpha=0,05$ dan memperoleh hasil bahwa $t_{\text {hitung }}<t_{\text {tabel }}(0,348<1,670)$. yang berarti Ho diterima dan Ha ditolak sehingga dapat disimpulkan bahwa tidak ada perbedaan antara hasil belajar siswa yang diajar dengan metode Think-Pair-Share (TPS) dan siswa yang diajar dengan metode Numbered Head Together (NHT).

Selama proses pembelajaran berlangsung, dengan menerapakan model pembelajaran Koopertaif TPS dan Kooperatfi NHT membuat siswa lebih antusias dalam belajar hal ini dapat dilihat ketika pembelajaran berlangsung motivasi siswa yang meningkat, rasa tanggung jawab yang meningkat dan banyak siswa yang aktif bertanya dan memberikan tanggapan saat ada temannya persentasi. Lie, (2003) menyatakan bahwa kegiatan ini berbeda dan menyenangkan, oleh karena itu materi yang disampaikan lebih mudah diingat; kegiatan ini menuntut siswa berpikir, mengingat, memprediksi dan menuntut semua siswa untuk terlibat. Ini membantu siswa pemalu ikut serta secara terbuka dalam kelompoknya. Hal ini sejalan dengan yang dikemukan Trianto (2009), pembelajaran kooperatif dapat memberikan keuntungan baik pada siswa kelompok bawah maupun kelompok atas yang bekerja bersama menyelesaiakn tugastugasnya.Tapi walaupun pembelajaran dengan model TPS lebih baik dari NHT, kedua model ini masih cocok diterapkan pada pembelajaran karena hasil belajar pada kedua model ini telah mencapai bahkan melewati KKM khususnya pada materi permaslahan lingkungan dikelas fakultas ekonomi.

Dengan diterapkannya model pembelajaran kooperatif TPS dan Kooperatif NHT siswa saling bekerja sama dengan siswa lainnya di dalam kelas pada saat berlangsungnya peroses belajar mengajar, siswa menjadi lebih termotivasi dan aktif, dan rasa canggung mereka untuk bertanya berkurang karena mereka bisa bertanya pada siswa yang lainnya dalam kelompoknya sehingga dapat meningkatkan hasil belajar siswa. dengan diterapkan model pembelajaran TPS dan NHT ini tujuan belajar dapat dicapai secara efisien dan efektif dalam suasana gembira dan bersaing.

Dari uraian diatas, peneliti menyimpulkan bahwa hasil belajar siswa yang diajar menggunakan model pembelajaran kooperatif Think-Pair-Share (TPS) dan Numbered Head Together (NHT) dapat meningkat hasil belajar siswa dan tidak ada perbedaan hasil belajar yang mencolok antara kedua model pembelajaran tersebut. Hasil uji-t yang dilakukan juga menunjukkan tidak adanya adanya perbedaan antara hasil belajar siswa yang diajar menggunakan model pembelajaran kooperatif TPS dan NHT pada materi pokok permasalahan lingkungan di kelas X SMA Cerdas Murni Tembung T.P 2012/2013

\section{KESIMPULAN}

Dari hasil penelitian yang dilakukan dapat diambil kesimpulan bahwa tidak ada perbedaan hasil belajar siswa yang diajarkan menggunakan model pembelajaran kooperatif Think-Pair-Share (TPS) dengan yang menggunakan model pembelajaran kooperatif Numbered Head Together pada materi matematika di Kelas II SMPN I Tanjung Morawa T.P 2015/2016 dengan nilai rata-rata $\bar{X}_{1}=83,00$ dan $\bar{X}_{2}=80,889$ 


\section{DAFTAR PUSTAKA}

Cipta, Jakarta

Arikunto, S., (2010). Prosedur Penelitian Suatu Pendekatan Praktik, Rineka

Arsyad, A., (2007), Media Pembelajaran, Pt Raja Grafindo Persada, Jakarta

Djamarah, S.B., (2006), Strategi Belajar Mengajar, PT Rineka Cipta, Jakarta

Drianti, D., (2011), Penerapan Model Pembelajara Koopertatif Tipe Think Pair Share Terhadap Hasil Belajar Siswa Pada Materi Klasifikasi Makhluk Hidup Kelas X Sma Swasta Al-Ulum Medan, Skipsi, FMIPA, UNIMED, Medan.

Hafiza, (2010), Perbedaan Hasil Belajar Siswa dengan Menggunakan Model Pembelajaran Kooperatif Tipe Numbered Head Together dengan tipe ThinkPair-Share Pada Sub Materi Pokok Sistem Indra di Kelas XI SMA N 1Negeri Gebang Tahun Pembelajaran 2009/2010, Skipsi, FMIPA, UNIMED, Medan.

Hartati, S., Sudarisman, S.,Perbedaan Pengaruh Pembelajaran Kooperatif Tipe Think Pair Share Dan Numbered Head Together Terhadap Prestasi Belajar Biologi Peserta Didik Kelas 8 Semester 1 Di SMP Negeri 12 Kota Magelang, Seminar Nasional VIII Pendidikan Biologi

Hasibuan E. A., (2010), Pengaruh Model Pembelajaran Kooperatif Tipe TPS (Think Pair Share) Terhadap Hasil Belajar Siswa Pada Materi Pokok Ekosistem Kelas X SMA Negeri 1 Barumun Kabupaten Padang Lawas, Skipsi., Skipsi, FMIPA, UNIMED, Medan.

Istarani., (2011), 58 Model Pembelajaran inovatif, Media Persada, Medan

Janes,(2002),Menjadi Guru Profesional ,Bandung PT.Remaja Rosda Karya

Karmana, O., (2007), Cerdas Belajar Biologi Untuk Kelas X Sekolah Menengah atas/madrasah Aliyah, Grafindo Media Pratama, Jakarta

Kurniawan, H., Istiningrum, A.A., (2012), Penerapan Metode Pembelajaran Kooperatif Teknik Think PairShare Untuk Meningkatkan Motivasi Belajar AkuntansiKompetensi Dasar Menghitung Mutasi Dana Kas KecilSiswa Kelas X Akuntansi 2 Smk Negeri 7 YogyakartaTahun Ajaran 2011/2012, Jurnal Pendidikan Akuntansi Indonesia, Vol. X, No.

Lasmiyatun, Saptaningrum,E., (2012), Implementasi Macromedia Flash Dengan Model Pembelajaran Kooperatif Tipe Think Pair ShareSebagai Upaya Peningkatan Hasil Belajar Siswa, Jurnal Penelitian Pembelajaran ISSN : 2086-2407 Vol. 3 No. 1

Lie, A., (2002), Mempraktikkan Cooperatif Learning Di Ruang - Ruang Kelas, Pt Grasindo, Jakarta

Parsono, Hardjanto, J., Kardiyo, Sugito, Ngatiyono., (2010), Pupin Modul Terpadu untuk SMA/SMP, CV SETI-SEJATI, Jakarta

Pratiwi, D.A., Maryati, S., Srikini, Suharno, Bambang, S., (2004), Buku penuntun untuk Pelajaran Kelas X, Erlangga, Jakarta

Pratiwi, D.A, Maryati, S, Srikini, Suharno, Bambang, S., (2007), Buku penuntun untuk Pelajaran Kelas X, Erlangga, Jakarta 
Sebayang, R., (2010), Perbandingan Hasil Belajar Siswa dengan Menggunakan Model Pembelajaran Model TAI (Teams Assisted individualization) dan Model NHT (Numbered Head Together) Pada Sub Materi Pokok Alat Indra Manusia di Kelas XI IPA Semester II SMA N 1Percut sei Tuan Tahun Pembelajaran 2009/2010, Skipsi, FMIPA, UNIMED, Medan.

Slavin, R. E., (2005),Cooperatif Learning Teori.Riset Dan Praktik, Nuasa Media, Bandung

Sudjana, (2001), Metode Dan Teknik Pemberlajaran Partisipatif, Falah Production, Bandung

Sudjana, (2002), Metode Statistika, Tarsito, Bandung 